\title{
Christomonism in Karl Barth's Evaluation of the Non-Christian Religions
}

\author{
P. Paul Knitter, SVD Marburg, Deutschhausstr. 19
}

One of the sharpest and most constant criticisms which Paul Althaus leveled against Karl Barth's views of the non-Christian world was that of Christomonism. ${ }^{1}$ Althaus felt that the basic lack and the abiding sin in Barth's evaluation of the religions was his narrow, restrictive, exclusive understanding of the reality of Christ, which bans all extra-Christian reality into the realm of meaninglessness and godlessness. Althaus, indeed, was not alone in such accusations. ${ }^{2}$. He voiced an objection which, he felt, every Christian theologian must make: because Barth's vision of Christ was too narrow, too "monistic", because he set undue limitations on Christ - he missed the breadth of God's plan of salvation and the religions' role in this plan. Barth' understanding of religion and the religions is christomonistic - and therefore to be rejected. ${ }^{3}$

Is such a diagnosis correct? Unfortunately, Althaus, like many of Barth's critics, never spelled out in detail just how Christomonism vitiated his views of the religions. Others, therefore, warn of oversimplifying or misinterpreting Barth's sweeping, harshly condemnatory statements on the religions." The "Theologischer Konvent Augsburgischen Bekenntnisses" in 1963 cautioned against making a "Popanz" of Barth's description of religions in the Kirchliche Dogmatik." And more recently

1 Cf. especially Die Christliche Wahrheit (Gütersloh, 1966, 7th ed.), pp. 56-60, 138; also, "Theologie und Geschichte, Zur Auseinandersetzung mit der dialektischen Theologie," ZSyTh 1(1923) 741-786, although in this early article Althaus does not use the term "Christomonism".

2 It was the question of God's activity outside of Christ which split the "Zwischen der Zeit" movement. Brunner's rejection of Barth's narrow views triggered the hefty "Nein" controversy in the 1930's. For Tillich it was Barth's "Supernaturalism" whith was untenable; cf. "What is Wrong with the 'Dialectical' Theology?" The Journal of Religion 15 (1935) 127-145, and "Natural and Revealed Religion", Christendom, 1935, pp. 159-170. In a different context but with the same intent, Bonhoeffer could accuse Barth of "Offenbarungspositivismus", in Widerstand und Ergebung, 1951, pp. 170, 184. Other contemporaries of Althaus who rejected Barth's doctrine on revelation were Fr. Brunstäd, H. Schreiner, Fr. Büchsel, Fr. K. Schumann.

3 Althaus, it should be noted, did not mercly criticize. His own positive efforts to correct Barth represent one of the earliest and most noteworthy attempts at a "Protestant Theology of the Non-Christian Religions". cf. Paul Knitter, "An Attempt at a Protestant Theology of the Non-Christian Religions: Paul Althaus", Verbum SVD, 11 (1970) 214-235.

4 W. Anderson, "Die theologische Sicht der Religionen auf den Weltmissionskonferenzen von Jerusalen (1928) und Madras (1938) und die Theologie der Religionen bei Karl Barth," Fuldaer Hefte, 16, Berlin, 1966, pp. 33-34, 54.

5 Report by Eugen Rose, ibid., p. 194. 
C. S. Song in a doctoral dissertation for Union Theological Seminary sweepingly affirms that those who criticize Barth's doctrine on the religions for its narrowness, have misread its deeper content: Barth's last word on the religions is positive! ${ }^{8}$ Finally it must be remembered that Barth's "cruelty" towards the religions was also aimed at Christianity. Can his final verdict therefore be totally negative or the product of Christomonism?

It is the purpose of this article to carry out and, in a sense, to test Althaus' diagnosis. We will examine Barth's most direct and succinct treatment of the religions - Paragraph 17 of his Kirchliche Dogmatik (to be referred to as KD 17) ${ }^{7}$ - for the presence of Christomonism. To do this properly, our analysis of KD 17 will be made in the light of Barth's early encounter with the religions in his Römerbrief (second edition referred to as $\mathrm{RB}){ }^{8}$ Such a study will indicate that Althaus' diagnosis, though simply and somewhat rashly stated, seems to be valid: Christomonism does form the deepest roots of Barth's evaluation of the religions. It was also the factor which marked the development of Barth's thinking on the religions from $\mathrm{RB}$ to $\mathrm{KD} 17$ and which made his final verdict all the more negative and harsh.

In concentrating on $\mathrm{KD} 17$ and $\mathrm{RB}$ we are, as is clear, limiting our study to Barth's early period.9 Such an apparently peremptory limitation is, we feel, justified by the following considerations:

- The Relation of Divine Revelation and Man's Religions in the Theologies of Karl Barth and Paul Tillich, 1965. Song's work will be referred to later. C. A. Keller also attempts a positive reinterpretation of Barth's doctrine on the religions but more in the light of his anthropology in later volumes of $\mathrm{KD}$ : "Versuch einer Deutung heidnischer Religion (im Anschluß an Karl Barths Lehre vom Menschen)", Ev. Missionsmagazin, 1956, pp. $70 \mathrm{ff}$.

7 I/2, (Zollikon-Zürich, 1960), pp. 304-397.

8 Zürich, 1940 - 2nd edition first published in München, 1922.

- The periods in Barth's theological maturation are not precisely definable. Precinding from his earliest years when he was still wandering in the Liberalism of his teachers Hermann and Harnack, we may distinguish two general periods: Exclusive Transcendence, extending approximately from 1922 to 1940, and Inclusive Transcendence, which went on to his death. The pulsing heart behind Barth's mammoth theological production is God's transcendence - the superiority and independence of the divine over the human. But in his first period Barth presented this transcendence in such a way as to "exclude" the human. This period may be divided into a philosophical and a theological phase. In the first phase, which extends roughly from 1922 to 1931 and is represented chiefly by the Römerbrief, Barth's starting point and method are clothed in philosophical-dualistic categories, especially those of Kierkegaard and Plato. In his Christliche Dogmatik of 1927 Barth sought to give his thought a more theological foundation and expression, but this first attempt was not entirely successful. His book on Anselm, 1931, marks the turning point at which Barth clearly affirmed Anselm's "credo ut intelligam" and took his stand soundly on God's Word as the sole foundation and starting point for his theology. On this foundation he was to construct the volumes of $\mathrm{KD}$. And on this foundation, gradually, Barth was to see God's transcendence as inclusive - not only rejecting 
1) It was during this period that Barth most explicitly confronted the religions and most clearly elaborated his views on them. ${ }^{10}$

2) The verdict he voiced during this period, more than any of his subsequent works, had a predominating and lasting influence on Protestant attitudes towards the religions. ${ }^{11}$

3) Even though Barth's Christomonism is reinterpreted and tempered in later volumes of $\mathrm{KD}$ - especially in such questions as Creation, III/1, pp. 44-377, Anthropology, III/2, pp. 82-241, the Analogia Relationis or Fidei, III/1, p. $207 \mathrm{ff}$. and $220 \mathrm{ff}$., the possibility of "other words" and other lights extra muros ecclesiae (IV/3, pp. 40-187) - his view of the non-Christian religions remains basically the same, i. e. dhristomonistic. This we hope to substantiate in a subsequent study.

\section{Extra Christum Tulla Revelatio (The staring point for Barth's evaluation of the religions)}

\section{A. KD 17: Christomonism}

The starting point and foundation of Barth's entire evaluation of the religions are found in the first paragraph of KD 17. Speaking of revelation as the reality which expresses the relationship between the divine and the human, Barth states, with utmost clarity, that this reality is solely in God's hands and absolutely outside of man's reach. In no way can revelation stem from, be prepared for, or be conditioned by the human. Revelation and man - God and man - come from two different worlds, and therefore any kind of "Zusammenspiel" between the two is absolutely excluded. Of himself, man has no "Organ", no "Anknüpfungspunkt", no "Eignung oder Aufnahmefähigkeit" for revelation. Both in its "Wirklichkeit und Möglichkeit", "Aktualität und Potentialität", revelation is entirely beyond man. In viewing (and experiencing) his position before God, man cannot speak of a "Können", "Bedürfen", "Müssen". All that can be said is: "Er kann nicht". (KD 17, 305, 328; cf. also KD I/2, $41-43)$

but affirming and embracing the human. This realization is still dormant in KD I $(1932-38)$ (perhaps because of the natural theology controversy with Brunner and the menacing "theological implications" of National Socialism), begins to stir in KD II (1940-42) and comes to full form in KD III (1945). (cf. Hans Urs von Balthasar, Karl Barth, Darstellung und Deutung seiner Theologic (Köln, 1962), pp. 99, 101-102, 116-117, 124; S. A. Matczak, Karl Barth on God (New York, 1962), p. 174; H. Bouillard, "Karl Barth", LThK, II, 5-8; G. Gloege, "Karl Barth", RGG I, 894-98.

10 Klaus Nürnberger calls KD 17 an "einschlägige Behandlung" of the religions which "... crlaubt eine für die Arbeit an Barth sonst selten erreichbare Konzentration der Analyse." Glaube und Religion bei Karl Barth (Inaugural-Dissertation, Philipps Universität, Marburg), 1967, p. 14.

11 C. H. Ratschow, "Religion, theologisch", RGG, V, 976; Peter Beyerhaus, "Zur Theologie der Religionen im Protestantismus", Kserygma und Dogma 15 (1969) 88-89; Hans-Werner Gensichen, "Wirklichkeit und Wahrheit der Religionen", Lutherische Monatshefte, Januar 1968, p. 95; Nürnberger, p. 134. 
Barth's starting point then is a theme which is heralded throughout his entire theological career: the transcendence of God and the finiteness of man, man's inability to find - even search for - God in and by himself, the necessity of God "doing all", the impossibility of beginning with anything human when speaking of the divine. This starting point might be called a form of "monism": in the mystery of communication between the divine and the human, only God is real; his activity precludes, absorbes, and in a sense negates all human activity.

But why? On what grounds does Barth proclaim this "monistic" understanding of revelation and of the relationship between God and man? The answer is given, indirectly, throughout KD 17 and constitutes a basic building block in Barth's theology: because of Jesus Christ! Because revelation has become a reality in Christ, it cannot be real anywhere else. That fact that God touched the world at one precise historical, mathematical point means, for Barth, that he comes into contact with the human (and vice versa) nowhere else. Barth's monism in KD 17 is a Christomonism.

This christomonistic understanding of God's activity is unveiled clearly in the two theological "facts" which for Barth are basic in judging the non-Christian world: God bas offered his "Selbstdarbietung und Selbstdarstellung" (revelation) (KD 17, $328 \mathrm{ff}$.), he has offered his "Gnade" (justification) (KD 17,335 ff.) once, in the reality of Jesus Christ. Only in him. Therefore, no revelation, no salvation anywhere else. Therefore, the total separation of the human and the divine. Therefore, the absolute inability of man to know God, to know revelation "so daß die Versuche des Menschen, Gott von sich zu erkennen, zwar nicht auf Grund einer prinzipiellen, wohl aber auf Grund einer praktisch faktischen Notwendigkeit, allgemein und gänzlich - umsonst sind" (KD 17, 328 , also 335-336). The practical, factual necessity stems from God's revelation in Christ - negating all other forms of revelation. All of man's attempts to know God, outside of Christ, are not only futile but counteractive; they not only miss the truth, but they fall into untruth, into a "Fiktion", into a "Gegengott" - all because "Wahrheit" is only in Christ (KD 17, 330-331).

This, for Barth, is the message of the New Testament: faith and contact with God become possible in Christ. Therefore they are possible nowhere else. Everything else is man's own "Werke" - the "Gesetz" which seals man's sinfulness and separation from God. (KD 17, 334-43).

Barth can even interpret the NT texts which traditionally have been the basis for a "general relevation" and a more positive theology of the religions. (Ro. 1, $18 \mathrm{ff}$; Ro. 2, 14; Acts 14, $15 \mathrm{ff} ; 17,22$ ) as o support for his Christomonism. Althaus terms Barth's exegetical feats with these texts 
"Künstlichkeit" and "rein aprioristisch-abstrakt".12 Firstly, Barth promptly dispatches the Ro. 2 text about the heathen "doing by nature what the law requires" as irrelevant since here Paul is speaking about Christian-heathen. (KD 17, 332; II/1, 131) ${ }^{13}$ Concerning the "general revelation" in Ro. 1, $18 \mathrm{ff}$, Barth again turns the tables: these statements of Paul must be understood as "Bestandteil des apostolischen Kerygmas ... nicht gelöst von der Situation der apostolischen Predigt, nicht gelöst von der Fleischwerdung des Wortes." Exegetically this may be correct, but Barth goes on to conclude: therefore, this revelation of God through nature can be real for man only in and after his revelation through Christ! In no way was Paul referring to an "Offenbarungsbesitz" for the heathen, in no way did he wish to "hook onto" ("anknüpfen") a knowledge of God which they had through a form of "Uroffenbarung". "Die Heiden haben eben die Erkenntnis von Ps. 19 prinzipiell nie auch im geringsten realisiert." - Barth even holds that the heathen cannot experience their own sinfulness, i.e. God's wrath, until they have met God's reality in Christ's revelations (identification of Law and Gospel). (KD 17, 334-335)

These texts therefore are really pointing out man's total inability to know God before Christ, i.e. the futility and sinfulness of all his attempts to find the divinity. This, according to Barth, is the intent of Acts 14, 15 and 17, $22 \mathrm{ff}$; Paul, standing in the light of Christ's revelation, could tell the heathen that the God they were seeking is the creator, the supreme, transcendent Lord of all; this means that all their attempts to know him not only fall short, but fall into idolatry: "Weil Gott der Schöpfer und also der Herr ist ... darum und nur darum können wir sündigen in Abgotterei." (KD 17, 333) In this sense God has not left man without a witness: "Denn eben in und mit der Verkündigung der Gnade in Christus (only then!) wird ihnen ja das Zeugnis Gottes aufgedeckt, von dem sie abgefallen, zu dem sie in radikalen Widerspruch geraten sind". (loc. cit.) Because God's truth has shone in Christ, all previous searchings for this truth are "der Wahrheit ... in einem Winkel von $180^{\circ}$ entgegengesetzt ... ein eigensinniges und eigenmächtiges Himmelstürmen . . . Gottlosigkeit und Unbotmäßigkeit”. (Kl) 17, 332-33)

'This then is Barth's interpretation of the NT's and the Reformers' "solus Christus". As Althaus sarcastically observes, Barth here "corrects" the Reformers: the "solus" must be taken as absolute and must apply not only to man's work, but also to his ability to know God: both have nothing to do with the real God. ${ }^{14}$ If God had not chosen to act in Christ,

12 Christliche Wahrheit, pp. 39, 59.

13 For Althaus this is a "reiner Verzweiflungsakt". Althaus argues that if Paul were speaking about Christians he would never sa y they fulfill the law "by nature" but by the Spirit. ibid., p. 40.

14 ibid., p. 57. 
perhaps things would be different; but because he did, we must draw the consequences. ${ }^{15}$ And on the basis of these christomonistic consequences the futility of the human because of Christ - Barth in KD 17 constructs his appraisal of the religions.

\section{B. RB: Immanentistic Monism}

In general, we may say that Barth's understanding of the relationship between God and man and the possibility of revelation in and through the human is just as "monistic" in RB as it is in KD 17. On every page of $\mathrm{RB}$, Barth presupposes and ruthlessly proclaims a Todeslinie between the divine and the human: the absolute difference and total separation between time and eternity, between the "Unanschaulich" and the "Anschaulich". The only relationship between the two is a contraryrelation which indicates a non-relation! God stands "in unendlichem qualitativen Unterschied" to man; he is man's "reine Grenze", and therefore "nie und nimmer identisch mit dem, was wir Gott nennen, als Gott erleben, ahnen und anbeten..." (RB 315) "Immer ist Gott dem Menschen jenseitig, neu, fern, fremd, überlegen, nie in seinem Bereich, nie in seinem Besitz..." (RB 96, cf. also 103) Looking at this situation from man's side, all Barth can say is: "Fleisch heißt radikalste Unzulänglichkeit des Geschöpfes gegenüber dem Schöpfer." (RB 63) Whatever is human and "anschaulich" - whether it be church or cult or history or religious experience - cannot establish contact with the divine, the transcendent, the "unanschaulich" (cf. RB, 33, 47, 105, 82, 220) And not only is man totally separated from God; also, any attempt he makes to bridge the gap and to hear a divine revelation will end up in "Ehrfurchtslosigkeit" and "Unbotmäßigkeit". Again, this is Barth's exegesis of Ro. 1, 18. $(\mathrm{RB}, 20)$

Therefore if God is to approach man, if he is to set up any kind of a contact and "reveal" himself, he will be able to do this only by pronouncing (or repeating) an absolute "Nein" to all that is human. "Anders als in der Negation des Geschöpfes ist die Position des Schöpfers und der

15 Other theologians - and perhaps Barth in later years - would draw different consequences: God's revealing and saving activity in Christ is not interpreted exclusively but cosmically; it does not negate other forms of revelation but assumes and affirms them. Barth's inability to do this is apparently due to the fact that he does not take the Incarnation seriously enough; the human is not fully and genuinely in all its aspects - assumed by the divine. cf. Regin Prenter, "Karl Barths Umbildung der traditionellen $Z$ weinaturlehre in lutherischer Beleuchtung", Studia Theologica 11 (1957), p 65. For the cosmic interpretation of Christ in ecumenical theology of the religions cf. J. Sittler, "Zur Einheit berufen", Neu-Delhi 1961, Dokumentarbericht, hrsg. v. W. A. Visser t'Hooft, (Stuttgart, 1962), pp. 512-523; Horst Bürkle, "Die Frage nach dem 'kosmischen Christus' als Beispiel einer ökumenisch orientierten Theologie," Indische Beiträge zur Theologie der Gegenwart, hrsg. v. H. Bürkle, (Stuttgart, 1966), pp. 248-65. 
ewige Sinn des Geschöpfes noch nic erkannt worden." (RB, 62) Revelation therefore comes in the form of an "Aufhebung" of all that went before it; it will always be a "no" to man, a pure beginning, an entirely "neue Welt", an absolute "Wunder", a reality which takes shape in a "Hohlraum". Here we feel the full impact of the Barthian "senkrecht von oben" ( $R B, 77,62,97,102-103,98,181-82,84)$

Even though KD 17 and RB present the same monistic view of revelation and communication between God and man, they differ in the foundation they give to these views. In KD 17 the foundation was theological or better, christological: Christomonism. In RB Barth bases his claims more on a philosophical standpoint which might be called immanentism..$^{18}$

This is due primarily to RB's "Sitz im Leben". Barth penned its pages amid the heat of his rejection of liberal theology and of the age's (and theology's) excessive concern with the human. This rejection was to be an enduring force behind all his theology. Yet, in these early years he began by fighting fire with fire; he took over as his first premise and starting point the age's immanentistic understanding of man and all reality: man is only man, he is entirely cut off from anything that is or might be beyond; all his undertakings are shackled within the border of his own visible world. Of course Barth would go on and, by appealing to God's Word, would say that is not the full picture; there is an answer to this situation. But the situation as it stands, he accepts - not so much on the basis of God's Word, but according to the "words" and in the dualistic categories of Plato, Kant, Dostojewskij, F. Overbeck, both Blumhardts and especially Kierkegaard. (RB, 234) ${ }^{17}$ Barth's monism, therefore, as we find it in $\mathrm{RB}$ is as Althaus states, not so much "eine theologische Nötigung (i. e. based on God's Word or on Christ), sondern eine bestimmte philosophische-weltanschauliche Haltung". Althaus can even call it "eine Art natürlicher Theologie negativen Inhalts"! ${ }^{18}$ Barth's monism in $\mathrm{RB}$ is not so much "Christic" as "immanentistic".

But is there any practical difference between Barth's immanentistic monism in $\mathrm{RB}$ and his Christomonism in KD 17? Both seem to be two sides of the same coin: in RB Barth begins with immanentism and concludes to Christomonism, i. e. since there is this unbridgeable rift between

16 This is not to say that a theological basis for Barth's monism in RB is entirely lacking. He points to both creation and sin as determining factors in the abyss between God and man. RB, 233; cf. Matuzak, p. 298.

17 Credo, München, 1935, p. 159; Evangelische Theologie, 1949, pp. 271-72; cf. also Barth's admissions in his acceptance specch for the Sonning Award in Kopenhagen, April 1963, quoted in H. Zahrnt, Dic Sache mit Gott (München, 1968), p. 29.

18 Christliche Wahrheit, pp. 56-57, 138; "Theclogie und Geschichte", 742-43, 753; J. Aagaard, "Revelation and Religion", Studiia Theologica 14 (1960) 158; Gloege, 895. 
the divine and the human, since revelation can in no way begin with man, therefore God can speak only in Christ. In KD 17 Barth starts with Christomonism and concludes to immanentism, i. e. since God has spoken only in Christ, therefore he speaks nowhere else, therefore there is the abyss between God and man. In RB, then, Barth begins with the Todeslinie and concludes to the "solus Christus"; in KD 17, he starts with the "solus Christus" and arrives at the Todeslinie. As Nürnberger argues, in $\mathrm{KD} 17$ Barth seems merely to be reversing his line of argumentation merely redressing RB's immanentism in theological garb. In KD 17 Barth realized that he had to discard the philosophical wardrobe of $\mathrm{RB}$ and of the Prolegomena and become more a theologian by arguing only from God's Word. Yet all he really does is restate and reconfirm his immanentistic position through what Nürnberger obtusely terms "das positivierte Negativ des Begriffes der Offenbarung": the positive fact of God revealing himself in Christ converges with and confirms the negative statement of immanentism, i. e. that man, by himself, is entirely separated from the divine. ${ }^{10}$ Essentially, though, there is no difference in Barth's understanding of the human.

Even though Barth's Christomonism in $\mathrm{KD} 17$ and his Immanentistic Monism in RB are similar in their general assertions, they show marked differences when applied to Barth's evaluation of religion and the religions. His Christomonism may have been "predetermined" by his immanentism, as Nürnberger holds; yet the fact that this immanentism receives a theological-christological foundation forces Barth into an all the more negative, harsh, and "monistic" understanding of the religions. (This Nürnberger does not point out.) Christomonism becomes the ultimate reason for his total condemnation of the religions. This we hope to prove in the ensuing pages.

\section{Extra Christum Nulla Religio}

\section{A. KD 17's Verdict: Total Rejection}

From his christomonistic premises - and with all the rigor of a Thomistic syllogism - Barth draws his conclusions on the religions. ${ }^{20}$ Everything he says about the religions is "in the name of revelation" -

10 Nürnberger, 25-30, 44, 61, 116; Nürnberger convincingly braces such claims by showing the strong influence which Feuerbach exercised on Barth at the time of $\mathrm{KD} 17$ 's composition. cf. pp. 49, 39-45, 50,59. Beyerhaus goes so far as to claim that under Barth's influence Feuerbach became a "negative Doctor Ecclesiae." op. cit., p. 89.

20 In this section we shall be referring to "religion" and "the religions" indiscriminately. All that Barth says here about religion in general can apply to every religion. He makes exceptions or restrictions only when speaking about the "justification" of religion - which is the topic of our next section. 
"indem die Offenbarung auf den Plan tritt..." (KD 17,335), "gemessen an der Offenbarung" (KD 17, 332) - i.e. revelation as coming exclusively in and from Christ. From this standpoint he can proclaim his sweeping verdict: "Religion ist Unglaube. Religion ist eine Angelegenheit, man muß geradezu sagen, die Angelegenheit des gottlosen Menschen" (KD 17, 327) The reasoning is clear: because revelation has come in Christ and only in him, religion must be seen as man's attempt to do what only Christ can do: reveal and please God. "Religion von der Offenbarung her gesehen (i.e. a christonomistic revelation) wird sichtbar als das Unternehmen des Menschen, dem was Gott in seiner Offenbarung (i. e. only in Christ) tun will und tut, vorzugreifen, an die Stelle des göttlichen Werkes ein menschliches Gemächte zu schieben, will sagen: an die Stelle der göttlichen Wirklichkeit, die sich uns in der Offenbarung darbietet und darstellt (i. e. only in Christ) ein Bild von Gott, das der Mensch sich eigensinnig und eigenmächtig entworfen hat." (KD 17, 329) Because the religions seek to do what has been done and can be done only in Christ, they are totally opposed to Christ and his revelation (KD 17, 320, 335); they are an abomination to God; in no way can they lead men to God, but only away from him. (KD 17, 337-338; 330-331)

Barth, at the same time, admits that for the human eye there are many similarities between the religions and Christ's revelation, that the same "Elemente und Probleme" are burning in the interior of all religions. He does not deny that there is human good to be found in the religions, and he refrains from all practical "negative Werturteile". Yet despite all these similarities and positive elements he insists that we must allow "das göttliche Urteil" to fall on the religions. If we take revelation seriously, i.e. revelation only in Christ, then all this possible religious good remains essentially and thoroughly Unglaube. (KD 17, 306-07; 327 ) Barth's view of the religions, then, is rooted firmly and incorrigibly in his Christomonism.

Barth also tries to give a "phenomenological proof" as a support for this theological-christomonistic verdic:. A study of the history and phenomenology of religions provides us, he argues, with a confirmation that religion is a purely "human affair" and is therefore "cin sich selbst widersprechendes, ein sich selbst unmögliches Unternehmen". (KD 17, 343) An analysis of Barth's "phenomenological proof", however, would seem to indicate that it is made through the glasses of his christomonistic principles.

Barth feels that running throughout the history of religions is a spontaneous "kritische Wendung" against religion, a natural rejection of religion. It comes primarily in the form of mysticism and atheism. Both react against and seek to remove religion in its principle manifestations: "die Gestaltung der Gottheit und die Erfüllung des Gesetzes." (KD 17, 344) Mysticism without wiping out the entirety of religion, would do a way with all external form; it interprets religion radically in a "gestalt- und werkloser Innenraum". Atheism is even more radical and aims at removing the gods. Both seek the same objective and complement each other; mysticism, despite its religious character, is an: esoteric atheism: "Die den Atheismus 
meinende Mystik und der die Mystik ... interpretierende Atheismus..." (KD 17, $347-348 ; 352$ ).

One might question Barth's interpretation of such a "Wendung". More pressing questions arise when he gives the reason for this "turn against religion". Mysticism and atheism, he states, reject religion and its laws and gods because they realize, implicitly and spontaneously, that religion is but a useless game which man is carrying on with himself. Man already has what he thinks he is seeking in religion: his "religiöser Besitz". In his gods and laws he already is in possession of the truth he thinks he is searching for. Religion is "... das spielerische Bedürfnis nach Veräußerlichung eines vor dieser Veräußerlichung und ohne sie bestehenden religiösen Besitzes". (KD 17, 344-47) Mysticism and atheism feel the futility of this game; they feel that religion is a "non-necessity".

But they do not fully realize why. Theirs is a blind, unconscious reaction. Barth goes on to explain the true basis and motivation of their action-and here, quite evidently, he puts on his christomonistic glasses. He explains the "religiösen Besitz": it is "das Vermögen, in der Welt und Mensch zu sein"! This is the origin of religion: man's being as man and his being in the world! This human, earth-bound "being" is related to religion "wie die Quelle dem Strom, wie die Wurzel dem Baum". Because this being-and nothing outside of this being-is the origin of religion, religion becomes useless; man is passing the time with himself. Mysticism and atheism themselves are nourished by this origin, i. e. by man's being; they themselves are simply different, more refined examples of man as closed and confined within himself. Therefore they cannot win the struggle against religion; therefore they will eventually fall into other forms of religion, into other expressions of man's "religiöser Besitz". Only Christ's revelation can break out of this "game" by showing not only the uselessness of religion but also its true origin: man's hidebound nature. (KD 17, 352-355)

Barth's "phenomenological" argument is clearly animated by and founded on his preconceived understanding of religion as originating only from man's "Vermögen in der Welt und Mensch zu sein". And such an understanding, as we have seen, is a demand of his Christomonism.

Having stamped the religions as "Unglaube" on the basis of his Christomonism, whether in its "theological" or "phenomenological" argumentation, Barth draws his practical conclusions. In no way may the theologian or missionary seek a relationship between revelation and the religions; in no way may he look for questions in religion for which revelation supplies the answers; in no way may he look for an "Anknüpfung". Here he is faced with an incorrigible "Entweder-oder". The "geringste Abweichung, die geringste Konzession" in this matter spells heresy. The one and only relationship revelation can have with the religions is that of "Aufhebung". (KD 17, 320-321; 330-331) But concessions have been made. "Religionismus" is for Barth the crying sin of Christian theology, whether in its Catholic form as the "analogia entis", or in its culminating Protestant expression in the modernism and "Neuprotestantismus" of the 19th and 20th centuries. (KD 17, 308-313)

All of this means that a "theology of religions" becomes impossible. Because Barth's Christomonism forbids any "concession" to the religions, the theologian who seeks after the "meaning" of the religions is stepping outside his domain, wasting his time - no longer a theologian. KD 17 by 
no means offers a theology of religions. Its purpose is merely to present all that is opposed to God's revelation - to clear the way. For Barth, the religions are only "a negative background to his own unique interest - revelation." ${ }^{21}$ This ostracizing of the religions explains why Protestant theology to this date has been so remiss in confronting the extra-Christian world. ${ }^{22}$ To give the religions a theological meaning is to betray the unique (monistic) role of Christ.

\section{B. RB's Verdict:}

\section{Rejection}

Because Barth's evaluation of the religions in RB was also based on his monistic understanding of revelation, it is similar to KD's verdict. But because this monism was not yet christic, there are also profound and refreshing differences.

Arguing in RB from his Kierkegaardian immanentistic starting point, Barth proclaims the same condemnation of religion that he does in KD 17. Firstly, the religions are confined to this side of the Todeslinie - they are purely and only buman, in no way able to step over into the world of the divine. The familiar, dualistic terminology is applied to the religions: "Was anschaulich wird, ist Religion und immer wieder Religion." (RB, 220) "Wer Gesetz, Religion, Erlebnis sagt, der sagt Werk des Menschen." ( $\mathrm{RB}, 83,63)$ Barth can even state that "... die religiöse Erregung vom Schlafbedürfnis nur durch Gradunterschiede getrennt ist." (RB, 217) Thus religion is only "Anschauliches, Hohlraum, Entbehren, Ungenügen" ( $R B, 98,88,114,83-84)$, a "Verlängerung der Natur" (RB, 164), a projection of man himself. (RB, 218-219; cf. also 62, 67; 193-194) It is the highest expression of what it means to be man - i. e. to be alone, cut off from God. (RB, 234-235)

This most gruesome expression of his humanity is also the means by which man constitutes himself a sinner. "Religion dient der Sünde als Hebel". (RB, 231, 249) "Durch sie (Religion) sind die Sündenleidenschaften gegeben, geweckt, in Kraft gesetz.t.." (RB, 218, 245) And all this takes place, Barth proclaims with pathos, in man's "höchste, letzte, hoffnungsvollste, tiefsinnigste, reinste, ‘äheste Möglichkeit", in the "Gipfel der menschlichen Möglichkeiten" (RB, 240, 164, 235, 55) - precisely here man becomes a sinner! Precisely here, where man reaches out for God, he proclaims himself a "Frevler"! Here is where he falls into the two fundamental sins of all religious understanding: the raising up of false gods and the attempt to save oneself through one's own works. It is

21 Aagaard, p. 158; Nürnberger, pp. 105-111, 116.

22 Ratschow, op. cit., 976; Ernst Benz, "Ideen zu einer Theologie der Religionsgeschichte," Akademie der Wissenschaften und der Literatur, Abhandlungen der Geistes- und Sozialwissenschaftlichen Klasse, 5 (1960) p. 32; Beyerhaus, p. 100. 
the proclamation of man's "Eritis sicut Deus" (RB, 20, 25, 63, 84-5, 98, $213,218,226)$

This is the same harrowing verdict we heard in $\mathrm{KD}$ 17: religion is Unglaube, sin. But in RB the origin of this sinfulness is different: whereas in $\mathrm{KD} 17$ the religions' sin stems from their usurpation of Christ's unique role, in RB it consists chiefly in the human attempt to cross the Todeslinie. This is allowed to no human (on the grounds of the Kierkegaardian cleft) and the religions are solely human. The sinfulness of the religious man is that he "verwechselt die Zeit mit der Ewigkeit. Er wagt was er nicht wagen dürfte; er greift hinaus über die ihm gesetzte Todeslinie (set by Kierkegaard!) nach dem unsterblichen unbekannten Gott ... Er macht Gott zu einem Ding unter Dingen in seiner Welt." (RB, 226) This "Verdinglichung und Vermenschlichung des Göttlichen" (RB, 53), this attempt "den Vogel im Fluge abzubilden" (RB, 163), this seeking to make "aus der lebendigen Abstraktion von allen Konkretheiten eine Konkretheit" $(\mathrm{RB}, 23)$ - this is the essence of the religions' sinfulness.

And therefore the religions must be "aufgehoben"! This is the same "conclusion" we heard in KD 17. When God's message of salvation arrives in the "Religionsjahrmarkt" then is proclaimed "das unvermeidliche Gericht über allen religiösen Betrug" ( $R B, 101)$, then the "falsche Münzen" must disappear ( $R B, 13)$. Because the religions seek to cross the abyss, they are a "Nichtseinsollendes", - and must "die" (RB, 106, 235, 112). Christ must be their total "Aufhebung" ( $R B, 315-16,252)$, their "gänzliche Erledigung". (RB, 216, 165)

\section{Partial Acceptance}

The religions then are purely buman, sinful, to be abolished. Yet this is not the whole picture. $\mathrm{RB}$ also presents another, a more positive view of the religions which, paradoxically, is blended with his negative view. Such a blending, such a positive side of the religions is lacking in KD 17; Christomonism would not allow it. This "partial acceptance" of the religions can be traced in their origin, function, and fulfillment.

As to the origin of religion, Barth cautiously states that although religion as we experience it today is confined to this side of the Todeslinie, its deeper sources spring from what he terms man's original identity with God, his original "Einheit mit Gott" (RB, 146), his "verlorene Unmittelbarkeit zu Gott" (RB, 212, 151), his "ewiger Ursprung" (RB, 224). Even though the might of sin has opened the Kierkegaardian abyss between time and eternity, Barth can still admit that "die auch durch die Sünde nicht abgebrochene Beziehung Gottes zu uns" remains. And vice versa, man's relation to God somehow still remains and dynamically makes up "eine bestimmte Qualifizierung aller Menschenzeit." (RB, 231 
-232) 23 - This "Verhältnis Gottes zum Menschen" which is "ursprünglich und anfänglich" is "die Voraussetzung der geschichtlichen Wirklichkeit der Religion." (RB, 104) Religion is a reality "... kraft des (bewußten oder unbewußten) Hergangs und Zustands seiner (man's) Beziehung zu Gott." (RB, 224) This would explain why religion is a universal phenomenon, why man has "keine andere Wahl, als irgendwie ein religiöser Mensch zu scheinen und zu sein" (RB, 212, 214,5) - It is clear from what we have said that this "lost origin" can never be realized or fully grasped in the religions; yet it is there. Such an admission is impossible in KD 17, for Christomonism demands that man' relationship to God be established and experienced solely in Christ. In KD 17, therefore, the sole "Quelle" of religion is man's "Vermögen in der Welt und Mensch zu sein." (KD 17, 354) Nothing else!

A to the function of religion, Barth can take a step further and, again cautiously and sometimes unclearly, speak about a form of revelation - "Offenbarungseindrücke" - before Christ, which somehow can be present in religion. (RB, 67, 225) These "impressions of revelation" are indeed of an "unbekanntem Gott", yet they provide a "Hinweis auf Gott ... auf die neue Welt" (RB, 40). "Zeichen, Zeugnis, Abbild, Erinnerung, Hinweis ist die geschichtliche Wirklichkeit allen Offenbarungseindrucks, Hinweise auf die Offenbarung selbst..." (RB, 105-106) They provide man with reminders, "Erinnerungen", "Anamnesis" of his original union with God ( $R B, 188,212,234,94)$, with "der irgendwie bestimmten Erkenntnis, daß er zu Gott gehört." (RB, 224) Barth calls these remembrances "... das Licht göttlicher Gegenwart und Offenbarung." (RB 151) They tell man that even though he is now shackled to the finite world, he is meant to be more; there is a "dualism" in his nature. (RB, $212,251-52)$ The incompleteness is expressed in the tensions, dissatisfactions, in the "Kampf" and "widerspruchsvolles Geschehen des Lebens". (RB, 359, 241) All of which, then, become a pointer to "Errettung" (RB, 359); whether expressed in Moses, or in John the Baptist or Plato or socialism, they can be "Berufung, Verheissung, Gleichnisfähigkeit ...", a "Symptom" of what God wills for man, "Gelegenheiten und offene Türen ... die, von Gott aus gesehen, zur Besinnung rufen, zur Erkenntnis leiten könnten," (RB, 53-54), "Möglichkeiten, Gelegenheiten, Zeugnisse für die Erkenntnis seiner Gerechtigkeit". (RB, 70) Barth, of course, insists that through the religions man will never achieve this knowledge ( $R B, 23)$; God's real revelation will always be beyond these impressions, never identified with them. $(R B, 67)$ Yet some form of enduring communication between God and man seems to be made possible. The "Ziel" cannot not be seen; but the "Wegweiser" remains. (RB, 62)

23 Therefore Barth could say in his introduction to RB that he wanted to trace the difference between God and man "in seiner negativen und positiven Bedeutung". $\mathrm{RB}, \mathrm{XIV}$, emphasis mine. 
Precisely in and by their insufficiency, - their failure - the religions realize their central function: to show man the tragic futility of his own attempts to reach the "Something" from which he has been separated and for which he is still meant. (RB, 232, 220) Barth interprets this primary role of the religions according to the traditional understanding of the Gesetz. In the religions man not only becomes a sinner (as we described above), he realizes he is a sinner. This is the "Sinn" of all religion: to lead man "zur Erfahrung seines Abfalls von Gott." (RB, 226; cf. also 241), "to allow sin to appear", (RB, 65, 164), to make sin an "anschauliche Gegebenheit unserer Existenz" (RB, 228, 224, 236). Thus the religions convince man that he cannot make it alone. They proclaim the "Krisis" and the "Katastrophe" of all that is human (RB, 224, 235), "die totale Fragwürdigkeit aller menschlichen Möglichkeiten" (RB, 56; cf. also 226), "die ganze Unzulänglichkeit seines (man's) Wissens und Wollens" (RB, 164). "Das ganze unerbittliche Halt" is erected before all his own attempts to rediscover his lost origin. (RB, 164)

By proclaiming this frustrating "Halt", the religions indirectly, negatively but truly prepare man for the "unmögliche Möglichkeit" God's intervention, God's "Ja" which takes shape in the burned-out structures of his "Nein". The deepest meaning and purpose of the religions Barth sees in their "Negativität". Precisely in their negativity, they are "höchster Hinweis auf die Positivität des Göttlichen innerhalb der menschlichen Realität." (RB, 213) In establishing this Nein they can "zum Glauben einladen" (RB, 106-107), they mark "den Punkt, wo alle menschlichen Möglichkeiten in das Licht der göttlichen treten", they direct man to "das Außerhalb der Humanität" (RB, 236-237, 105). Barth holds that the religions "die Augen schärfen" for that which "wir über die Grenzen der Religion hinweg bereits (!) ausschauten.” (RB, 239) Religion sets the limits of mankind, "damit uns jenseits der Grenze, die durch sie bezeichnet ist, Gott begegne." (RB, 224)

Barth therefore sees a certain negative necessity in the function of the religions. God's Ja requires a Nein. Grace cannot enter mid-stage until religion has first played its role and "negatively prepared" the way. "... das Überströmen der Gnade, das in jedem zeitlichen Augenblick ohne das 'Uberfließen' der Sünde in der Religion nicht geschehen kann." (RB, 165; cf. 114-115) If the religions must be "aufgehoben", this Aufhebung is necessary for the further construction of God's plan; in a negative sense, God needs the religion. We should not try to "avoid" or "set aside" the religions. (RB, 224) Barth admits a "relative Anerkennung", a "relatives Recht" for religion. He can even say: "Und Religion $\mathrm{zu}$ wecken, wachzuhalten, und zu pflegen, vor allem aber zu reformieren, nein immer wieder zu revolutionieren, ist eine Aufgabe, die wahrlich, wenn irgendeine innerhalb der Humanität, des Schweißes der Edlen wert ist." (RB, 237) 
To allow the religions this negative role of the Gesetz becomes absolutely impossible in KD 17 - simply because Christ becomes the Gesetz. Only in him can man feel the reality of his sinful, helpless, needy position. Barth's Christomonism destroys Luther's - and Paul's - understanding of the law and robs the religions even of a possible negative role in salvation (KD 17, 339-40; 395). ${ }^{24}$

Because of the religions' lost but still actual divine origin, because of their negatively necessary function, Barth can also speak, sometimes quite glowingly, of a real fulfillment of the religions (not just religion!) in Christ. He is "das Ziel, von dem alle menschliche Religion Zeugnis gibt ... das Ziel der menschlichen Bedürfnisse, Wünsche und Strebungen" which are expressed in the religions. (RB, 359) Barth dares to call God's justification in Christ “... die Erfüllung aller Verheißung ... den Sinn aller Religion ... die Beantwortung alles menschlichen Hoffens." $(R B, 70)$ Christ's light is "... das Licht aller Religionsgeschichte und Wahrheitsgeschichte, das Weihnachtswunder, auf das die ganze Adventswelt der Natur und der Geschichte, der sichtbaren und unsichtbaren Kreaturen hinblickt als auf die Erfüllung ihres Wartens"! (RB, 93) Indeed, this fulfillment and this answering will always be something entirely beyond the religions, never "ein Teil, nicht eine Strecke," of the history of religions. The eternal "Nein" must be spoken over the religions - but precisely through this negation the religions and their content of "Offenbarungseindrücke" are "nicht ausgelöscht, nicht vernichtet, sondern bestätigt, bewährt und bekräftigt." In their Aufhebung, they find their meaning and fulfillment. Therefore their "Gericht ist nicht Vernichtung sondern Aufrichtung. Reinigung ist nicht Entleerung, sondern Erfüllung." (RB, 5253) We can speak of a "negative fulfillment" of the religions in Christ. - Such a fulfillment of "Religionsgeschichte" - of the religions - becomes in KD 17 completely inadmissable. As we shall see in the next section, Barth's Christomonism permits Christ to be the "Sinn" of only one religion ${ }^{25}$.

24 Nürnberger, pp. 167-68; Althaus, Christliche Wahrheit, p. 59. By 1927 Barth's understanding of the Gesetz had changed; he no longer identified the religions with the law. This came about during his Calvin studies while lecturing in Münster. of. Ulrich Mann, "Religion als thcologisches Problem", Christentum und Religion (Regensburg, 1966), p. 65-67.

25 The "partial acceptance" of the religions which we have sketched in this section belongs to what Barth later called a "rechte "theologia naturalis"” which he fell into in his earlier works "... zuletzt noch sehr handgreiflich in dem Aufsatz 'Kirche und Kultur' 1927 und an manchen Stellen meiner im selben Jahr erschienenen 'Prolegomena'." (cf. "Nein. Antwort an E. Brunner," p. 7; also KD I/1, p. VIII; also Heinrich Leipold, Theoric der Verkündigung. Der Streit um die Frage der 'Anknüpfung' zwischen E. Brunner und K. Barth, Habilitationsschrift, handschr., Marburg, 1969 , p. $345 \mathrm{ff}, 324-29,332-37$.) 


\section{In Christo Una Religio}

\section{A. KD 17: Justification of One Religion}

There are passages in KD 17 which seem to indicate a much more positive attitude toward religion than anything we found in RB. Clearly, directly, Barth states that God's revelation must also have a "human", a "subjective" side. In order to be a "dem Menschen widerfahrendes Ereignis" it must assume "die Gestalt menschlicher Zuständlichkeit, Erfahrung und Tätigkeit..." (KD 17, 305) And this means that revelation must also be religion! (KD 17, 308) God' revelation becomes his presence in the world of religions. (KD 17, 306-07) Perhaps we have interpreted Barth's christomonistic understanding of revelation too harshly. The "Aufhebung" of religion through revelation also has a positive meaning. It assumes religion; it implies not only "destructio" but also "elevatio". ${ }^{26}$ This is implied in Barth's summary of KD 17: "Gottes Offenbarung in der Ausgießung des Heiligen Geistes ist die richtende, aber auch versöbnende Gegenwart Gottes in der Welt menschlicher Religion..." (KD 17, 304, emphasis mine) And more clearly: "Die Aufhebung der Religion durch die Offenbarung braucht nicht bloß zu bedeuten: ihre Negation, nicht bloß das Urteil: Religion ist Unglaube. Die Religion kann in der Offenbarung, obwohl und indem ihr jenes Urteil gilt, wohl aufgehoben, sie kann von ihr gehalten, und in ihr geborgen, sie kann durch sie gerechtfertigt werden..." (KD 17, 357) Religion, like the sinner, can be justified. This is certainly more than the "negative fulfillment" we found in $R B$.

But when Barth goes on to describe this "Rechtfertigung", he reveals it as the epitome of his christomonistic understanding of religion, for he insists that justification of religion can take place: 1) only in the reality of Jesus Christ and 2) in a way in which nothing is taken over or "answered" from the world of religions. The justification applies only to $a$ religion; not to the religions.

"Only in the reality of Jesus Christ" - all of Barth's positive statements about religion in KD 17 are tied solely - "christomonistically" to this condition. Barth clearly admits that for him religion can have a positive value and be "justified" only according to the schema of the assumptio carnis. Religion is related to revelation as Christ's human nature to the divine person: the unity between the two is limited to a "vollendetes Geschehen". Before this event, before this "assuming", Christ's human nature had no meaning; it existed only as a possibility.

26 Aagaard, pp. 164-167; Benkt-Erik Benktson, Christus und die Religion, Der Religionsbegriff bei Barth, Bonhoeffer und Tillich (Stuttgart, 1967), pp. 62-63; W. A. Whitehous in The Scottish Journal of Theology 14 (1961) 146, stresses the positive content of "Aufhebung" and would translate it with "superseding". 
The same can be said of religion. (KD 17, 323-324) Only "als Annex der menschlichen Natur Jesus Christi" can it have any kind of positive meaning. (KD 17, 382) ${ }^{27}$

Therefore, if Barth admits "in seiner Offenbarung ist Gott gegenwärtig mitten in der Welt menschlicher Religion", then this can be said only "in Erinnerung an die christologische Lehre von der assumptio carnis"; i. e. this presence is limited to "jenem Geschehen zwischen Gott und Mensch". KD 17, 324) Barth's vocabulary indicates how he jealously limits the justification of religion to the historical, definable, visible reality of the Incarnation. "... die offenbare Gottestatsache des Namens Jesus Christus ... bezeichnet ... ein ganz bestimmtes Geschehen (!), an dem die Welt der Religionen einen ganz bestimmten Anteil bekommt." Only one religion is justified. "Die Gottestatsache (!) des Namens Jesus Christus bestätigt ... was keine andere Tatsache bestätigt noch bestätigen kann, die Schöpfung und Erwählung gerade ihrer Religion zur einen, einzigen (!), wahren Religion." (KD 17, 390-391) "Daß es eine wahre Religion gibt, das ist Ereignis im Akt der Gnade Gottes in Jesus Christus..." (KD 17, 377) Only that religion which is linked to this "Geschehen", to this "Tatsache", "Ereignis", "Akt" - only that religion which is "Eigentum Christi", and is in his "Bereich und Reich" (KD 17, 322) - only this religion is lifted "aus der Menge der anderen als die wahre Religion". (KD 17, 357) Outside of Christ, als Calvin held, religion is only "... eine Größe x, die ihren Inhalt und ihre Form nur (!) dadurch empfängt, daß sie von der Offenbarung in sich aufgenommen und zu ihrer Gestalt gemacht wird." (KD 17, 310; cf. Instit. I, 3, 1f; 1, 4, $1 ; 12,1)^{28}$ Here, then, we have Barth's christomonistic interpretation of the religions at its blatant best.

This justification takes place in such a way that nothing really is assumed from the world of religions (not even a "negative content" cf. above). If Christianity is justified in Christ, this does not depend on or have anything to do with its quality as "religion". Here we can understand Barth's remarks about Christianity not being different from other religions. The Christian religion's justification in no way implies an "immanent content of truth or value" (KD 17, 369) - a truth it might share with other religions. Nor does it have any kind of "religious selfconsciousness as such" (KD 17, 364). If one looks at this "true religion", one surprisingly finds no external differences from the other false religions: the same "göttliche Anklage auf Götzendienst und Werkgerech-

27 cf. Aagaard, p. 169.

28 And this, it would seem, is the essential lack in Song's dissertation, referred to above: he fails to realize that all of Barth's positive statements on "religion" are limited to the context of the "assumptio carnis". Where Barth speaks of this one religion being justified in Christ, Song too hastily read "the religions". cf. op. cit., pp. $106-124,296$. 
tigkeit" (KD 17, 378), the same sad story of "Unglaube und Sünde", the same "Widerspruch"against God's grace (KD 17, 389, 369). This true religion shows ". . . in ihrer Gestalt, aber auch in ihrer menschlichen Wurzel sündige Geschichte, nicht weniger, als dies von der Geschichte des Buddhismus oder des Islam zu sagen ist." (KD 17, 387)

How, then, is Christianity the true religion? The answer again lies deep in Barth's Christomonism. The justification of religion is related so "exclusively" to Christ that nothing of religion as religion plays a role in this justification; one can even say that nothing of religion as religion is really effected by this justification. All comes from Christ and, in a sense, remains with him. This is best seen in the image Barth uses to describe the justification of religion: as the light of the sun falls on one part of the earth and not on the other, enlightening one part and leaving the other in darkness, without really changing the earth, so Christ's light falls on the world of religions, making one of these religions light and true and leaving the rest in darkness and falsehood - but without bringing any essential change to the true religion. (KD 17, 388) All depends, simply, on the sun shining here and not there, on the "Akt der göttlichen Erwählung". "Die christliche Religion ist darum die wahre Religion, weil es ... Gott ... gefallen hat, nun gerade sie als die wahre Religion zu bejahen ..." (KD 17, 384) This is what Barth means when he says that Christianity is the true religion "durch die Gnade Gottes" or "durch den Namen Jesus Christus" - simply that God's grace shines on her, Christ's name is spoken over her and therefore she is the true religion. Her sin, her resistance to grace, her idolatry remain - but they are forgiven in the sunlight of Christ; God speaks his "Ja" over her. (KD 17, 379-380, $363,369,389)$ This is the essential, the only difference between Christianity and the other religions: Christianity stands in this sunlight. No matter how good and true the other religions may be, they are false, useless - because they are not in this light.

Barth gives an example: he compares Christianity with the Buddhistic "grace religions" of Jodo-Shin and Jodo-Shin-Shu. These religions have a remarkable grasp of the basic truth of Chistianity - that all must come from God through grace, that man is totally helpless to save himself. (KD 17, 372-374) But even if their doctrine of grace and faith would be exactly the same as that of Christianity, even then, Barth insists, the drastic difference would remain! The grace-religions would be false, useless; only the Christian religion would be true. Why? "Entscheidend über die Wahrheit und Lüge ist wirklich nur Eines ... dieses Eine ist der Name Jesus Christus, (der) ganz allein die Wahrheit unserer Religion ausmacht!" (KD 17, 376) Only Christianity stands in the light of Christ's name. The truth of a religion, therefore, lies not in its religious doctrine of grace, but in the "Wirklichkeit der Gnade selbst" - only through this reality "wird die eine Religion von anderen als die wahre angenommen und ausgezeichnet". (KD 17, 371) And only Christianity has this reality!

Stating it somewhat simply, we might say that the Christian religion is the true religion because we can place the word "Christian" in front of it. Or as Nürnberger puts it, the justification of religion consists 
essentially and exclusively in Christ becoming the Subject of religion without really changing the "Aktinhalt" of religion, i. e. without really changing religion itself. Christ "takes over". He becomes, as it were, the new driver; which means indeed that the course of the vehicle is changed, but the vehicle itself remains the same. In the religions, man is the subject; in Christianity Christ becomes the subject; but in the "Aktinhalt" of both, there is no real difference. ${ }^{29}$ Christ, in other words, does not really assume religion; religion remains essentially what it was.

Once it is understood that Chrianity's truth does not lie in its quality of religion but only in its having the "Tatsache" of Christ as its subject, Barth admits that certain secondary changes take place. Christianity's justification does include its santification. God is "wirklich erkannt und verehrt" and "ein Handel des mit Gott versöhnten Menschen" takes place. (KD 17, 377) In Christ, Christianity is "ausgesondert, durch ihn geformt und gestaltet, für seinen Dienst in Anspruch genommen, zur geschichtlichen Erscheinung und zum geschichtlichen Mittel seiner Offenbarung". (KD 17, 393) She is given an "Auftrag" and a "Mission" to step before the other religions "zum Einlenken auf den christlichen Weg einzuladen und aufzufordern". (KD 17, 392, cf. also 395) And yet, Barth continually insists that such positive characteristics in Christianity are only "symptoms", only "signs" of a reality which is constantly beyond her and never identified with her. (KD 17, 372, 377) They in no way can be "proofs" for her truth or for the truth of any religion. Truth lies solely in Christ as the subject of a religion of one religion.

Our initial assertion would now seem to be a valid conclusion: Barth's understanding of the "justification of religion" represents the final and fullest expression of his Christomonism. Because religion can be justified in Christ, it has absolutely no meaning, or purpose or value outside of Christ. Only in Christ can the "subject" of religion be changed. To allow this to take place outside of Christ, i. e. outside of the Christian religion, would be to contradict the reality of Christ as a "Tatsache", as a unique "Geschehen". But even in Christ religion has no meaning of itself; it remains human, immanent. Therefore, there is no possibility whatsoever of relating Christianity to the other religions, of bringing about any kind of encounter. ${ }^{30}$ One might compare the contents of Christianity with the contents of other religions and even though one may find some similarity, even identity, one has not yet touched that which makes Christianity the true religion: its Subject. This is something entirely beyond the religions, somethings "incomparable". In his christomonistic understanding of Christianity's "truth" Barth has relativized the Christian religion phenomenologically (as to the "Aktinhalt" there is no difference from other religions) but has absolutized it theologically (its "Subject" is totally and absolutely removed from the world of religions).

29 Nürnberger, pp. 66-70, 123-127; also id., "Systematisch-theologische Lösungsversuche zum Problem der anderen Religion en und ihre missionsmethodischen Konscquenzen," NZSyThR, 12 (1970) 16-24.

30 Aagaard, pp. 179-80; Nürnberger, pp. 123-124. 


\section{B. RB: Justification "extra Christum sed propter Christum"}

$\mathrm{RB}$, as would be expected, does not contain such an extended and integrated statement on the possibility of religion's justification as KD 17 does. In RB Barth's primary intent was to trace clearly the lime between time and eternity and to let God pronounce his "no" over all that is human - especially the religions. He did not yet focus on God's "yes" in Christ - a singular "yes" which included the singular justification of religion. Yet even in RB Barth - less clearly, less frequently, and more cautiously - allows for a certain "assuming" and acceptance of religion in the process of justification. He admits religion as a necessary "unvermeidlicher seelischer Reflex (Erlebnis) des an der Seele sich ereigenden Wunders des Glaubens." Religion becomes a "Zeichen und Zeugnis" of faith. (RB, 105) More generally, Barth sees religion as a necessary "Begleitungserscheinung des Glaubens" because faith also must have its "gesetzliche", visible, subjective side. (cf. RB, 110, 162, 212) Thus Barth can even venture to say: "Es gibt eine Rechtfertigung der religiösen Gebärde." (RB, 113)

But the essential and crucial difference between $R B$ and KD 17 is that in RB the possibility of religion's justification is not rooted so firmly and exclusively in Barth's Christomonism. In RB Barth does not affirm the justification of religion according to the "analogy" (which is really more than an analogy) of the assumptio carnis. The possibility of God assuming or making use of religion is not limited explicitly to the unique, singular "Tatsache" and particular "Geschehen" in which he took on flesh; religion in RB is in no way compared (and identified) with Christ's human nature. This is seen from the context in which Barth speaks of religion's justification. In $\mathrm{RB}$ he does so usually by relating and subordinating religion to faith ( $R B, 105,110,113,162)$, i. e. that mysterious reality in which God asserts his priority and transcendence and accepts man's nothingness. In $\mathrm{KD} 17$ Barth explains religion's justification by its relation and subordination to revelation, i. e. that unique, historical reality, taking place only in Christ. (KD 17, 306-07, 327, 329, 332) In RB, then, Barth seems content with the more general principle that religion can have meaning only by bowing to the divine transcendence; in $\mathrm{KD} 17$ this act of reverence and subordination must take place through the unique, historical expression of this transcendence in Jesus Christ's revelation ${ }^{31}$.

And because in $R B$ the justification of religion is not yet so clearly admitted nor jealusly restriced to the reality of the assumptio carnis, it is understandable that Barth in RB does not speak of " $a$ true religion". $\mathrm{He}$ does not yet speak in the singular, i. e. about one religion being lifted

s1 This is not to say that in RB Barth did not hold that faith is possible only in Christ; yet this dependence was not tied so explicitly to Christ as a "unique event". 
out of the morass of religious history and being assumed by the divine Subject.

True, in the last pages of RB Barth does turn his eyes directly to the Church; he does admit that the Church is in posession of God's Word (RB, 325), that "das ewige Licht ... leuchtet ihr..." so that the "unmögliche Möglichkeit Gottes ... liege im Bereich ihrer Möglichkeiten". (RB, 358) A certain "Aufnahme" of the Church by God takes place ( $R B, 391)$, a possible justification (RB, 381); the Church receives a mission and an "Aufgabe". (RB, 402) And yet, Barth's treatment of the Church in RB is pronouncedly different from his presentation of Christianity as the true religion in KD 17.32 In RB Barth does not explicitly insist that the Churd's role is unique, exclusive, that only she is the "subjektive Wirklichkeit der Offenbarung", that only in her can religion be taken over by Christ and have a meaning. On the contrary, Barth sees the role of the Church as that of carrying out the role of all religions - fully, completely, to the last frustrating limits. More than the other religions, she fails in her task; the possibility of hearing God's Word and accepting his light is not realized. (RB 372, 325) She could be ("wäre") a religious "Ort" different from the religions but this possibility escapes her. (RB, 362, 372-73) She could be "the Church of Jacob" (the true religion), but she remains "the Church of Esau". (RB 326, 324-44) She too "makes a creature" out of God; she too becomes an "Aufhebung" of the Gospel (RB, 316-17); she too falls into atheism (RB, 375). Thus she is the very last "menschliche Möglichkeit", the "Kathastrophe der menschlichen Gipfelmöglichkeit" (RB, 377), where man's opposition to God attains its "sublimste ... Form" (RB, 403). - The difference (the only difference!) is that in Christ the Chruch knows - she believes that God can accept this failure; that he can pronounce his "yes" in the midst of this "no"; that man must first be crushed in order to be raised up. (RB, 375-78, 381) All this happens in her, but it is not really defineable or traceable in her, not limited to her; it also happens beyond her. (RB, 383) Because God pronounces his "yes", invisibly, paradoxically in the Chruch, this "yes" echos through the universe. Thus the Church, by being (like the religions) nothing but "Not und Schuld" and by realizing that God accepts this "Not und Schuld", becomes "die Hoffnung des Menschen überhaupt, die unerhörte Rechtfertigung und Rettung alles dessen, was der Mensch, nichtwissend was er tut, unternimmt und vollendet". (RB, 404, 387-88) The Church's difference from the religions would seem to be that she knows God can do in her what he can do outside her: accept and justify man. The other religions do not know this. ${ }^{33}-$ In KD 17, God also pronounces his "yes" over the sinful, insufficient Christian religion; but this "yes" seems to be limited to her. She alone is "die einzige, wahre Religion".

32 Balthasar, p. 98.

3s One cannot help noting the similaritics between this aspect of Barth's ecclesiology and modern Catholic explanations of the Church's "Heilsnotwendigkeit" as the "signum universale salutis". The Church's salvific instrumentality is found in her being the unique, historical, and enduring sign of God's "yes" to man in Christ. Because this "yes" is spoken and heard in the Church, it is also to be found outside the Church, in other religions. Naturally, Barth's view differs fundamentally as to how the Chruch is a sign of salvation. cf. Second Vatican Council, Dogmatic Constitutation on the Chruch, par. 1, 16, 48; Decree on the Missionary Activity of the Chrurch, par. 1; Karl Rahner, "Christentum und die nichtchristlichen Religionen", Schriften zur Theologie, V, pp. 136-158; id., Schriften VI, "Konziliare Lehre der Kirche und künftige Wirklichkeit christlichen Lebens", Schriften VI, pp. 479-488; Johannes Feiner, "Kirche und Heilsgeschichte", Gott in Welt, Vol II (Freiburg, 1964), pp. 317-345; Hans Küng, "The World Religions in God's Plan of Salvation", Christian Revelation and World Religions (London, 1967), pp. 25-66; Edward Schillebeeckx, "The Chruch and Mankind", Concilium, 1 (1965) 34-50. 
Thus Barth in RB clearly states that God can carry on his work of justification among other religious men, outside the Curch, outside Christ (but always because of Christ). "Durch Jesus ... haben wir die Augen bekommen, zu sehen ..." that "vor und nach Jesus ... viele wandeln im Lichte der Erlösung ... daß Gott allenthalben gefunden wird." (RB, 71). We understand that there are "... überall, auch in den Tiefen, Zugänge zu Gott." (RB, 44-45) "Immer und überall war Vergebung der Sünden ..." (RB, 64) God's love and his ability to justify are free, unable to be contained in any one event. "Gott ist frei." (RB, 370) Thus the true Church, the Church of Jacob, in which "das Wunder geschieht"and man is justified, is universal, "... ohne Ausdehnung noch Beschränkung, ohne Ort noch Namen ... ohne Mitgliedschaft noch Ausschluß dieser oder jener, rund in ihr ist Gottes freie Gnade, Berufung, und Wahl Eins und Alles." $(\mathrm{RB}, 326)$

Of course, we cannot argue that this freedom and universality of God's grace implies a justification of the religions as religions. Barth explicitly warns against concluding to a "religiöses Apriori" behind all the religions which would give them a value of their own. (RB, 370) Yet, because Barth in RB does not christomonistically hold to only one religion in Christ, he could - indirectly and implicitly - allow the religions to have a certain share or play a certain role in justification. Naturally this will never be anything more than the negative, dialectical, contradictory role played by the Church herself.

We have already seen how Barth can allow the religions (like the Church) to carry out the negative work of the "Gesetz" - i.e. to convince man of his total insufficiency and thus prepare him for God's "yes" in Christ. Barth also describes the possible justification of the heathen in the same way he portrays the justification of Christians: in their religious undertakings, in their "good works" in their mislead, futile searching for God. God can overlook all this; his "Erbarmen" can accept what his "Zorn" should reject. (RB, 344-45; also 50) The "Werke des Gesetzes" among the heathen (their religions!) can become "von Gott aus betrachtet, etwas Wertvolles, Schätzbares, Ausgezeichnetes." (RB, 64), just as the insufficiency of the Christian religion (its Aktinhalt) is mysteriously accepted and justified by Christ (receives Christ as its subject). All this takes place beyond the religions; yet also, in them.

Barth also directly admits that the heathen as heathen, "in ihrer heitern Kreatürlichkeit und Weltlichkeit, in der schlichten anspruchslosen Sachlichkeit ihres Tuns sind ... von Got erkannt und erkennen ihn wieder ... sind nicht ohne Ausblick auf den silbernen Rand von Erlösung und Vergebung." Thus their life - and this would imply their religion - can be a "Gleichnis ... vielleicht ein so vollkommenes Gleichnis, daß es schon darin seine Rechtfertigung hat." (RB, 41). Finally, because God's revelation is free and because it can find "ein neues Flußbett" outside the 
Jewish and Christian religions - “... darum ist es doch ein Irrtum, die 'Heiden' so ohne weiteres Schläfer, Ungläubige und Ungerechte zu nennen. Auch sie können Gottesfürchtige, von Gott Erwählte sein - ohne andern als solche kenntlich zu werden." On the basis of this revelation, channeled through their religions, Barth hints at "eine befremdliche Form von Glauben" among the heathen. (RB, 41-42)

Also in KD 17 Barth admits that the heathen are embraced in Christ's redemption (KD 17, 324), but according to the demands of his Christomonism, he in no way can allow the religions to share or play a role in this justification. Just how the heathen are saved remains an open question (to be answered at the end of time). In the meantime, if "Gott den gottlosen Menschen samt seiner Religion aus Gnade versöhnt" (KD $17,326)$, then this religion can only be Christianity. Otherwise Jesus Christ does not remain Jesus Christ!

Conclusion: Althaus' diagnosis would seem to be correct: if Barth in $\mathrm{KD} 17$ felt he could not allow any form of revelation in the religions, if he had to brand the entire history of religions as "Unglaube", if he could permit the justification of only one religion - then he did so only in the name of Jesus Christ, i. e. because of his monistic understanding of Christ. ${ }^{34}$ In RB, where his Christomonism was not yet fully formed, his views on the religions were tempered. - Our study of Barth makes clear that any "theology of the religions", whether Reformed or Luthern or Catholic, is linked essentiaily to Christology. Our ability to understand the religions and to dialogue with them will be determined by our understanding of Jesus Christ.

34 As stated above, the question whether Barth's Christomonism in later volumes of KD changed sufficiently enough to enable him to view the religions differently must be answered in a further study. 